\title{
GENETICAL VARIATION FOR ENZYME ACTIVITY IN A POPULATION OF DROSOPHILA MELANOGASTER. VI. MOLECULAR VARIATION IN THE CONTROL OF ALCOHOL DEHYDROGENASE (ADH) ACTIVITY
}

\author{
A. J. BIRLEY, P. A. COUCH and A. MARSON \\ Department of Genetics, The University of Birmingham, P.O. Box 363, Birmingham, \\ B15 2TT, England
}

Received 10.xii.80

\section{SUMMARY}

\begin{abstract}
Four characters, ADH activity at $25^{\circ}$, immunologically determined ADH protein level, total protein and body weight were measured upon 72 hour old adult female and male Drosophila melanogaster from 16 highly inbred lines, derived from the laboratory population, "Texas"' (established 1966). The highest levels of ADH activity and ADH protein level were observed in the 2 lines homozygous for the $A d h^{F}$ allele. Amongst the $14 A d h^{S / S}$ lines variation for ADH protein level was associated with genetical variation for $\mathrm{ADH}$ activity $(\hat{r}=0 \cdot 6)$. The genetical association between ADH activity or ADH protein level and either body weight or total protein in the 16 inbred lines was not statistically significant. A study of $\mathrm{ADH}$ activity, ADH protein and total protein in 8 lines representing all homozygous combinations of chromosomes I, II and III and derived from two inbred $A d h^{S / S}$ lines, chosen for their respective high and low ADH activities, showed that $\mathrm{ADH}$ activity was considerably modified by a post-translational event controlled from chromosome III. Total protein was controlled by different chromosomal effects from those controlling ADH activity. Michaelis constants for crude fly extracts of the two $A d h^{F / F}$ and the above two $A d h^{S / S}$ lines showed clear differences in affinity for isopropanol.
\end{abstract}

\section{INTRODUCTION}

THE phenotypic variation for alcohol dehydrogenase (ADH) activity is, in most natural and laboratory populations of Drosophila melanogaster, strongly associated with the electrophoretically identified $A d h^{F}$ and $A d h^{s}$ alleles; these alleles generally confer high and low ADH activities respectively (Rasmuson et al., 1966; Gibson and Miklovich, 1971; Day, Hillier and Clarke, 1974; Hewitt et al., 1974; Ward, 1975; Lewis and Gibson, 1978). Two mechanisms have been attributed to the association between the electrophoretically detected phenotype and enzyme activity. The mechanisms, which may occur together, are:

(1) ADH-F enzyme has a higher intrinsic catalytic activity per molecule than ADH-S enzyme (Day et al., 1974).

(2) An association of the $A d h^{F}$ allele with loci (or locus) that broadly modify enzyme activity, for example, by increasing the level of ADH protein. Such associations have been demonstrated both in a natural population (Lewis and Gibson, 1978) and in strains of diverse origin (Day et al., 1974).

(3) Genetical differences in the structural gene or its immediate vicinity which regulate the accumulated quantity of $\mathrm{ADH}$ enzyme, as is suggested by the studies of Gibson (1975) and Maroni (1978). 
Studies of the inheritance of ADH activity in true-breeding lines derived from the long-established population, "Texas", have shown that $A d h^{F}$ and $A d h^{s}$ alleles contribute substantially to the phenotypic variation in ADH activity (Birley and Barnes, 1973; Birley, Marson and Phillips, 1980). Modifier gene action, in particular from chromosome III, also affects the activity of strains homozygous for the $A d h^{s}$ allele (Barnes and Birley, 1978). The adaptive significance of loci which modify the level of ADH protein has, like the difference in activity between ADH-S and ADH-F enzymes (Gibson, 1970; Morgan, 1975; van Delden et al., 1978) been related to survival in the presence of environmental ethanol (McDonald et al., 1977).

The aims of the present study are two-fold:

(1) to obtain a clearer understanding of the biochemical properties of the genetical variation for $\mathrm{ADH}$ activity in the population of inbred lines derived from the "Texas" population

(2) to present our results so that experimental design may be appraised and any limitations of previous studies concerning the genetical control of $\mathrm{ADH}$ activity may be assessed.

We consider this is necessary since $\mathrm{ADH}$ activity variation is of wide interest and there is reason to criticise some of the metrics used to describe continuously varying features of the enzyme phenotype such as ADH activity or immunologically determined $\mathrm{ADH}$ protein level as well as some aspects of experimental design and procedure (Clarke et al., 1979; Birley et al., 1980). In many studies of the genetical control of ADH and other enzyme activities the precise source of error variance is difficult to ascertain. Indeed this study demonstrates that most appropriate source of error variance can vary between characters. We therefore present the results and analysis of the variation between lines for the four characters, ADH activity, $\mathrm{ADH}$ protein, body weight and total protein in such a form that the sources of error variation used in tests of significance can be assessed.

\section{MATERIALS AND METHODS}

Sixteen highly inbred lines, extracted from the laboratory population, "Texas" (see Birley and Barnes, 1973), were used in this study. Flies were raised in $\frac{1}{3} \mathrm{pt}$ milk bottles on $50 \mathrm{ml}$ of food medium which consisted of $15 \mathrm{~g}$ Agar (Kobé), $15 \mathrm{ml}$ Nipagin $\mathrm{M}$ (10 per cent w/v solution in 98 per cent ethanol), $8.75 \mathrm{~g}$ Fowlers' black treacle, $180 \mathrm{~g}$ oatmeal (Mornflake, fully stabilised) and $395 \mathrm{ml}$ water. A suspension of $0.75 \mathrm{ml}$ live bakers' yeast was added to each bottle one day prior to use. The experimental design varied with the three experiments, hence each will be described in turn. Details of the four measurements, ADH activity, ADH protein, body weight and total protein are also given below.

\section{(i) Characterisation of the inbred lines}

The 16 inbred lines were raised once in duplicate culture. All of the cultures were individually randomised with respect to their position upon the incubator shelf. Virgin female and male flies were collected from the cultures and aged individually for 72 hours following eclosion. Two females 
and two males from each duplicate culture and from each inbred line (128 flies in all) were sampled from the pool of flies which had been collected. These flies were then divided into 4 groups (blocks). Two blocks each consisted of 32 females, one from each duplicate culture of each inbred line. The other two blocks each consisted of 32 males, one from each duplicate culture of each inbred line. Live body weight was determined for each individual in random sequence with respect to inbred line and duplicate culture within each block. Subsequent determinations of ADH activity, $\mathrm{ADH}$ protein and total protein were all carried out upon the same individual flies. Therefore, for all of these determinations the 32 flies within each of the four blocks were placed in a randomised sequence with respect to inbred line and duplicate culture.

\section{(ii) The chromosome substitution lines}

Two lines, namely 15 and 25 , were selected from the set of "Texas" inbred lines for their respective high and low $\mathrm{ADH}$ activities. A set of eight chromosomal substitution lines representing all true breeding combinations of chromosomes I, II and III were then derived from 15 and 25 using a chromosome balancer stock characterised for chromosome II as In (2L + 2R) Cy, Cy cn ${ }^{2} / \operatorname{In}(2 \mathrm{LR}) P m a l^{4} d s^{33 \mathrm{k}} l t b w^{v i}$ and for chromosome III as $\operatorname{In}(3 \mathrm{LR}) D c x F, D / S b$. There was no evidence that recombination with the balancer stock had occurred during the construction of these lines for genes controlling ADH activity (Barnes and Birley, 1978). The eight lines were grown in duplicate cultures in a single randomised block. A sample from each of the sixteen cultures was kept at $-20^{\circ}$. Two virgin female flies were taken at random from each of these samples on five occasions over a period of 14 days, and the three characters ADH activity, ADH protein and total protein were measured on every fly 72 hours after eclosion. Hence 32 individually randomised flies were each assayed for the three characters on five occasions and the total experimental size here was 160 flies.

\section{(iii) Determination of $A D H$ activity and Adh protein}

$\mathrm{ADH}$ activity (mU) was measured on centrifuged supernatant at $25^{\circ}$ with an LKB Reaction Rate Analyser 8600 coupled to an LKB reaction rate calculator 8200 . Further technical details are given by Birley and Barnes, 1973; Barnes and Birley, 1975.

The immunological determination of $\mathrm{ADH}$ protein was carried out using the technique of Laurell (1966). A Tris-borate-EDTA buffer system was used for immunoelectrophoresis (Day et al., 1974) and ADH antiserum was raised in New Zealand white rabbits to partially-pure and electrophoretically homogeneous ADH-F enzyme. Partial purification was carried out at $0^{\circ}-4^{\circ}$ following the methods of protein precipitation, gelexclusion and ion-exchange chromatography described by Sofer and Ursprung (1968) to yield a relatively stable preparation of ADH-F enzyme. Partial purification of the enzyme was used in order to minimise any possible effects of partially specific antibodies in the immunological tests. Studies of the antiserum by immunoelectrophoresis and immunodiffusion (Ouchterlony, 1967) against either ADH-F or ADH-S enzyme showed 
that the two allele products were immunologically equivalent. The 1 per cent $w / v$ agarose (Koch-light laboratories) gel plates contained 12 per cent $\mathrm{v} / \mathrm{v}$ for the study of the sixteen "Texas" inbred lines and 7.5 per cent $\mathrm{v} / \mathrm{v}$ for the study of the chromosomal substitution lines. Immunoelectrophoresis was carried out with $1 \mu$ l of crude fly extract for 24 hours at $4^{\circ} \mathrm{C}$, after which the "Laurell rockets" were stained by standard procedures for ADH activity. The peak height of the "rockets" produced by the Laurell chnique was measured in millimetres and found to be directly related to both the concentration of pure and crude enzyme preparations save for those peaks near to the cathodal wick. The concentrations of antiserum used in the two studies then differed (see above) so as to maintain the variability in peak height within the linear range of enzyme concentration.

\section{(iv) Determination of total soluble protein and body weight}

The total soluble protein per fly was estimated upon the supernatant of individual flies following a modification of the turbidometric technique described by Mejbaum-Katzenellenbogen and Dobryszycka (1959). The results as $\mu \mathrm{g}$ per fly were estimated relative to calibration with bovine serum albumen. Live body weight was measured to the nearest $10 \mu \mathrm{g}$ on a Cahn electrobalance model 7550 .

\section{(v) Michaelis constants}

Adult flies were collected from four of the sixteen "Texas" inbred lines namely $6,15,19$ and 25 . Crude fly homogenates consisted of 96 flies of each line in $5 \mathrm{ml}$ ice-cold $0.05 \mathrm{M}$ Tris-phosphate buffer $p \mathrm{H} \mathrm{8.5}$. The homogenate was centrifuged at 5000 r.p.m. for 30 minutes at $4^{\circ}$. Reaction rates for all four lines were determined in a $6 \times 6$ matrix of concentrations of the two substrates propan-2-ol and $\beta-\mathrm{NAD}^{+}$, with $100 \mu \mathrm{l}$ aliquots of supernatant. This procedure was carried out on four separate occasions. Details of the estimation of the Michaelis constants are given in section 3(iii).

\section{Results}

\section{(i) The inbred lines}

Mean values of the four characters ADH activity, ADH protein, body weight and total protein are presented in table 1 . The analyses of variance (table 2) and the expected mean squares (table 3) show that items 4-8 inclusive contribute to the variation between lines. A Bartlett test of variance homogeneity upon items $4-8$, proved significant in the cases of body weight and total protein only. Accordingly item 1, "lines", was tested against the appropriate error variances for all four characters (see table 2).

There is extensive variation between lines but not between sexes for $\mathrm{ADH}$ activity and ADH protein. The three partitions of item 1 show that the differences between lines homozygous for the electrophoretically identified $A d h^{F}$ and $A d h^{S}$ alleles make a substantial contribution to the genetical variation in both $\mathrm{ADH}$ activity and $\mathrm{ADH}$ protein. Nonetheless 
TABLE 1

Mean values of $A D H$ activity, $A D H$ protein (Laurell rocket height in $\mathrm{mm}$ ), body weight, total protein and the ratio of $A D H$ activity to $A D H$ protein for the 16 "Texas" inbred lines. Lines 6 and 19 are homozygous for the $\mathrm{Adh}^{\mathrm{F}}$ allele, the remainder are homozygous for the $\mathrm{Adh}^{\mathrm{S}}$ allele

Line

1
5
6
7
8
9
10
15
16
17
18
19
20
25
27
28

$\begin{array}{rc}\text { ADH } & \text { ADH } \\ \text { activity } & \text { protein } \\ 3.89 & 37.0 \\ 4.04 & 31.5 \\ 17.22 & 58.0 \\ 4.53 & 34.9 \\ 4.29 & 30.0 \\ 3.65 & 43.8 \\ 5.01 & 43.3 \\ 6.54 & 43.5 \\ 6.41 & 38.6 \\ 3.50 & 30.3 \\ 5.79 & 40.3 \\ 20.09 & 64.9 \\ 6.06 & 39.9 \\ 3.32 & 39.1 \\ 3.00 & 27.6 \\ 7.34 & 42.1\end{array}$

Body
weight $(\mathrm{mg})$
0.65
0.72
0.84
0.77
0.79
0.80
0.97
0.74
0.84
1.02
0.95
1.01
1.04
0.95
0.64
0.91

Total
protein $(\mu \mathrm{g})$
$29 \cdot 9$
$38 \cdot 9$
$43 \cdot 2$
$37 \cdot 1$
$37 \cdot 0$
$38 \cdot 2$
$61 \cdot 1$
$35 \cdot 6$
$42 \cdot 5$
$57 \cdot 3$
$40 \cdot 1$
$41 \cdot 8$
$60 \cdot 0$
$46 \cdot 2$
$26 \cdot 8$
$42 \cdot 7$

ADH
activity/protein
0.11
0.13
0.30
0.13
0.14
0.08
0.12
0.15
0.17
0.12
0.14
0.31
0.15
0.08
0.11
0.17

heritable variation is also manifest between the $14 A d h^{S / S}$ lines for both characters and between the $2 A d h^{F / F}$ lines for ADH activity.

In contrast, the statistically significant variation between lines for body weight is entirely due to variations within the electrophoretic classes and not to difference between the $A d h^{S / S}$ and $A d h^{F / F}$ lines. There is a highly significant difference between sexes for both body weight and total protein. However, it is important to note that the sexes and lines interaction is highly significant for total protein only. Therefore, the expression of variation in total protein, between the lines, is sex-dependent.

Following the notation of Mather and Jinks (1971) the proportion of heritable variation in a set of inbred lines is $D /(D+E)$. In the present case the variation between lines $\left(\sigma_{1}^{2}\right)$ is equal to $D$, the additive genetical variation and $E$, the environmental variance is the pooled error variance, item 10, table 2. The heritabilities of $\mathrm{ADH}$ activity and $\mathrm{ADH}$ protein level for all 16 inbred lines were 84 per cent and 47 per cent respectively. Exclusion of the two lines homozygous for the $A d h^{F}$ allele gave the reduced heritabilities of 24 per cent and 16 per cent respectively. This further illustrates the close association between electrophoretic phenotype and the variation between lines for ADH activity and ADH protein level.

Pairwise correlation coefficients (table 4) calculated from the line means are used to illustrate associations between all four characters. The correlation between $\mathrm{ADH}$ activity and $\mathrm{ADH}$ protein (fig. 1) is strongest when both $A d h^{F / F}$ lines are included.

It is also apparent (table 1) that the molecular activity, expressed as the ratio of $\mathrm{ADH}$ activity to $\mathrm{ADH}$ protein is about 2.5 times higher in $A d h^{F / F}$ lines than in $A d h^{S / S}$ lines. Hence the strong association between $\mathrm{ADH}$ activity and ADH protein level has at least two biochemical and genetic bases; a molecular difference associated with ADH-F and ADH-S 


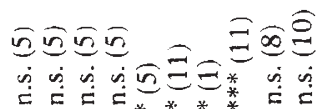

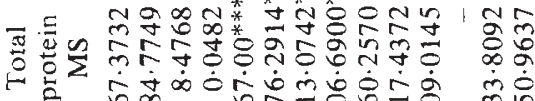

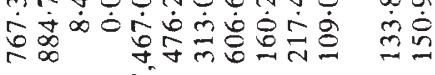

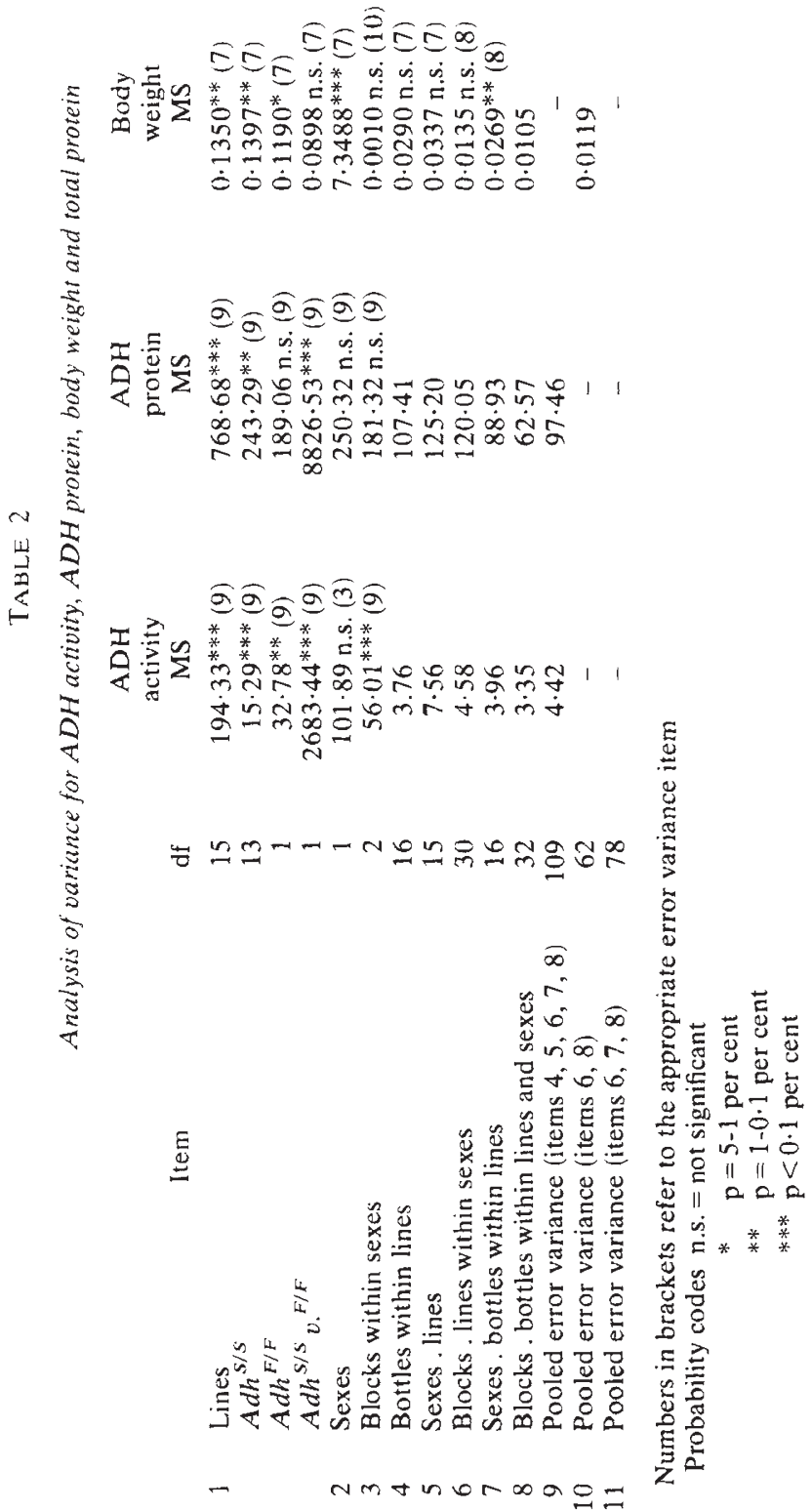


TABLE 3

Analysis of variance structure

\begin{tabular}{|c|c|c|c|c|c|}
\hline & Item & $\mathrm{df}$ & & EMS & \\
\hline 1 & Lines & 15 & $\sigma_{8}^{2}+2 \sigma_{7}^{2}$ & $+2 \sigma_{6}^{2}+4 \sigma_{5}^{2}+4 \sigma_{4}^{2}$ & $+8 \sigma_{1}^{2}$ \\
\hline 2 & Sexes & 1 & $\sigma_{8}^{2}+2 \sigma_{7}^{2}$ & $+2 \sigma_{6}^{2}+4 \sigma_{5}^{2}$ & $+32 \sigma_{3}^{2}+64 \sigma_{2}^{2}$ \\
\hline 3 & Blocks within sexes & 2 & $\sigma_{8}^{2}+$ & $2 \sigma_{6}^{2}$ & $+32 \sigma_{3}^{2}$ \\
\hline 4 & Bottles within lines & 16 & $\sigma_{8}^{2}+2 \sigma_{7}^{2}$ & $+4 \sigma_{4}^{2}$ & \\
\hline 5 & Sexes . lines & 15 & $\sigma_{8}^{2}+2 \sigma_{7}^{2}$ & $+2 \sigma_{6}^{2}+4 \sigma_{5}^{2}$ & \\
\hline 6 & $\begin{array}{l}\text { Blocks . lines within } \\
\text { sexes }\end{array}$ & 30 & $\sigma_{8}^{2}+$ & $2 \sigma_{6}^{2}$ & \\
\hline 7 & $\begin{array}{l}\text { Sexes. bottles within } \\
\text { lines }\end{array}$ & 16 & $\sigma_{8}^{2}+2 \sigma_{7}^{2}$ & & \\
\hline 8 & $\begin{array}{l}\text { Blocks . bottles within } \\
\text { lines and sexes }\end{array}$ & 32 & $\sigma_{8}^{2}$ & & \\
\hline
\end{tabular}

TABLE 4

Correlations between characters. Values above the leading diagonal of the matrix correspond to the correlation for all 16 lines. Values below the leading diagonal relate to the $14 \mathrm{Adh}^{\mathrm{S} / \mathrm{s}}$ lines

$\begin{array}{lcccc} & \begin{array}{c}\text { Body } \\ \text { weight }\end{array} & \begin{array}{c}\text { Total } \\ \text { protein }\end{array} & \begin{array}{r}\text { ADH } \\ \text { activity }\end{array} & \begin{array}{r}\text { ADH } \\ \text { protein }\end{array} \\ \text { Body weight } & - & 0.84^{* * *} & 0.30 \text { n.s. } & 0.37 \text { n.s. } \\ \text { Total protein } & 0.90^{* * *} & - & 0.05 \text { n.s. } & 0.15 \text { n.s. } \\ \text { ADH activity } & 0.29 \text { n.s. } & 0.21 \text { n.s. } & - & 0.90^{* * *} \\ \text { ADH protein } & 0.33 \text { n.s. } & 0.28 \text { n.s. } & 0.59^{*} & -\end{array}$

Probability values as for Table 2

enzymes and strain difference in the level of ADH protein associated mainly with the $A d h^{F / F}$ and $A d h^{S / S}$ lines.

Associations of either body weight or total protein with either ADH activity or ADH protein level are weak, not statistically significant and do not depend upon ADH electromorph. Finally, whilst body weight and total protein individually show little overall variation between lines they are closely related to one another. Therefore these results also raise doubt as to the wisdom of scaling $\mathrm{ADH}$ activity or $\mathrm{ADH}$ protein level by either body weight or total protein.

\section{(ii) The chromosomal substitution lines}

A posteriori inspection of the line means (table 1 ) showed that the difference in ADH activity between lines 15 and 25 was not entirely associated with ADH protein level. Previous studies with a set of eight chromosomal substitution lines comprising all homozygous combinations of chromosomes I, II and III, derived from lines 15 and 25, had shown that the variation in $\mathrm{ADH}$ activity between these 2 lines was controlled from chromosomes, other than chromosome II, which carries the $A d h$ structural gene (Barnes and Birley, 1978). The same set of chromosomal substitution lines was used to ascertain chromosomal contributions to the three characters $\mathrm{ADH}$ activity, ADH protein and total protein for flies raised in contemporary culture. Mean values for the three characters are shown in table 5 and the analyses of variance followed the design described 


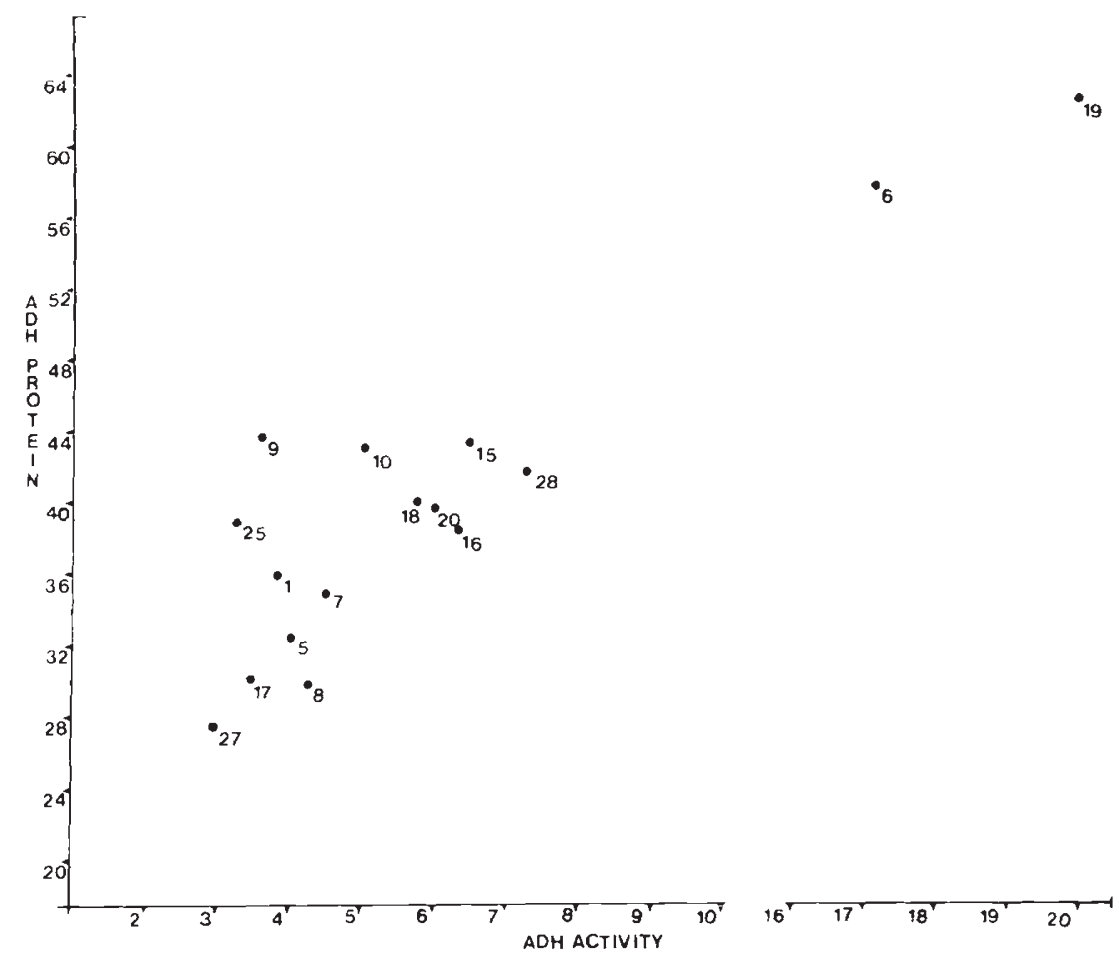

FIG. 1.-Relationship between line means for ADH protein and ADH activity. Lines 19 and 6 are $A d h^{F / F}$, the remainder are $A d h^{S / S}$.

by Barnes and Birley (1978). The results of the analyses of variance showed that chromosome III had a marked effect upon variation in $\mathrm{ADH}$ activity, the X-chromosome effected a smaller contribution and neither the effect of chromosome II nor any chromosomal interaction was statistically significant. For ADH protein level none of the effects of individual chromosomes or their interactions were statistically significant. The genetical

\section{TABLE 5}

Mean values for $A D H$ activity, ADH protein level and total protein for the chromosomal substitution lines

\begin{tabular}{cccccc}
\multicolumn{3}{c}{ Line/constitution, } & ADH activity & ADH protein & Total protein \\
I & II & III & & & \\
H & L & L* & $2 \cdot 47$ & $41 \cdot 3$ & 42.9 \\
H & H & L & $2 \cdot 86$ & $35 \cdot 3$ & $35 \cdot 2$ \\
H & L & H & $5 \cdot 07$ & $39 \cdot 5$ & $38 \cdot 3$ \\
H & H & H & $5 \cdot 81$ & $39 \cdot 8$ & $49 \cdot 7$ \\
L & H & H & $6 \cdot 27$ & $39 \cdot 3$ & $49 \cdot 1$ \\
L & L & H & $6 \cdot 02$ & $33 \cdot 3$ & $45 \cdot 7$ \\
L & H & L & $2 \cdot 61$ & $39 \cdot 0$ & 36.3 \\
L & L & L & $2 \cdot 82$ & $40 \cdot 2$ & 46.9
\end{tabular}

* $\mathrm{H}$ and $\mathrm{L}$ denote chromosomes derived from lines 15 and 25 respectively 
control of total protein was effected by a small contribution from chromosome III and a larger effect due to an interaction between chromosomes II and III. Control experiments showed that a difference in $\mathrm{ADH}$ activity between lines 15 and 25 due to a difference in $\mathrm{ADH}$ protein level, would have been detected as a chromosomal effect in this experiment. Hence this experiment confirms the views that (i) $\mathrm{ADH}$ activity and total protein level are largely under independent control and (ii) variation in $A D H$ activity between the $A d h^{s / s}$ lines can be caused by modification(s) unrelated to the level of ADH protein and electromorph.

\section{(iii) Enzyme kinetics}

Michaelis constants were determined for the two $A d h^{S / S}$ lines, 15 and 25, and for the two $A d h^{F / F}$ lines, 19 and 6 . It will be recalled that the molecular activities of lines 19 and 6 were much higher than those of $A d h^{S / S}$ lines. This group of 4 lines was chosen since lines 15 and 25 differed from both $A d h^{F / F}$ lines in their molecular activity. Lines 19 and 6 also differed in their direction of dominance when crossed to $A d h^{S / S}$ lines (Birley et al., 1980) which could also be a reflection of underlying differences in their kinetic properties. No differences of enzyme structure could be gleaned between the two $A d h^{F / F}$ or between any of the $A d h^{S / S}$ lines from gel electrophoresis studied in a range of $\mathrm{pH}$ 's and ionic strengths or by isoelectric focussing.

It is assumed that the kinetics of Drosophila $\mathrm{ADH}$ follows a compulsory order ternary-complex mechanism. Only the forward reaction was studied, hence $\beta-\mathrm{NAD}^{+}$is the leading substrate. The direct linear plotting procedure described by Eisenthal and Cornish-Bowden (1974) was used to estimate the three parameters $\mathrm{Ki}^{\mathrm{NAD}}, \mathrm{Km}^{\mathrm{NAD}}$ and $\mathrm{Km}^{\text {ISOP }}$ (table 6) from secondary plots of the data. The results are expressed as median values together with their 95 per cent non parametric confidence limits which were calculated by the methods of Cornish-Bowden, Porter and Trager (1978). We will confine our attention to well-defined differences in the Michaelis constants. Lines 19 and 25 have different values of $\mathrm{Km}^{\mathrm{NAD}}$

\section{TABLE 6}

Michaelis constants (as $m M$ ). Lines 6 and 19 are homozygous for the $\mathrm{Adh}^{\mathrm{F}}$ allele and lines 15 and 25 are homozygous for the $\mathrm{Adh}^{\mathrm{s}}$ allele. $K_{i}^{N A D}$ is the dissociation constant for $\beta-N A D^{+}$ when the concentration of isopropanol approaches zero, $K_{m}^{N A D}$ is the limiting Michaelis constant for $\beta-N A D^{+}$(isopropanol saturating) and $K_{m}^{I S O P}$ is the limiting Michaelis constant for isopropanol $(\beta-N A D$ saturating)

\begin{tabular}{|c|c|c|c|c|c|c|c|c|}
\hline \multirow{3}{*}{$\begin{array}{l}\text { Constant } \\
K_{m}^{N A D}\end{array}$} & \multicolumn{2}{|c|}{$6\left(A d h^{F / F}\right)$} & \multicolumn{2}{|c|}{$19\left(A d h^{F / F}\right)$} & \multicolumn{2}{|c|}{$15\left(A d h^{S / S}\right)$} & \multicolumn{2}{|c|}{$25\left(A d h^{S / S}\right)$} \\
\hline & & $+0 \cdot 16$ & & +0.05 & & +0.06 & & +0.08 \\
\hline & 0.17 & -0.07 & $0 \cdot 34$ & $-0 \cdot 14$ & 0.20 & -0.06 & $0 \cdot 10$ & -0.04 \\
\hline$K_{m}^{I S O P}$ & 1.49 & $\begin{array}{l}+0.51 \\
-0.23\end{array}$ & 1.79 & $\begin{array}{l}+0.76 \\
-0.52\end{array}$ & 0.70 & $\begin{array}{l}+1.06 \\
-0.55\end{array}$ & 0.75 & $\begin{array}{l}+0.56 \\
-0.44\end{array}$ \\
\hline$K_{i}^{N A D}$ & $0 \cdot 20$ & $\begin{array}{l}+0.28 \\
-0.24\end{array}$ & 0.25 & $\begin{array}{l}+0.43 \\
-0.11\end{array}$ & 0.26 & $\begin{array}{l}+0.14 \\
-0.06\end{array}$ & 0.21 & $\begin{array}{l}+0.49 \\
-0.16\end{array}$ \\
\hline
\end{tabular}


whilst the values for lines 6 and 15 are intermediate with limits that overlap those of 19 and 25 . Both $A d h^{F / F}$ lines have much higher values of $\mathrm{Km}^{\text {ISOP }}$ than the two $A d h^{s / S}$ lines.

Hence ADH-F and ADH-S enzymes differ in Vmax and $\mathrm{Km}^{\mathrm{ISOP}}$. Similar, but less pronounced, differences in Vmax and $\mathrm{Km}$ are also apparent in the data of Day et al. (1974) for the substrate ethanol.

\section{Discussion}

In the present study the ratio of $\mathrm{ADH}$ activity to $\mathrm{ADH}$ protein for both $A d h^{F / F}$ lines is about twice the value of the largest ratio found amongst the fourteen $A d h^{S / S}$ lines. Hence increased ADH protein level is not the only component of activity variation between $A d h^{F / F}$ and $A d h^{S / S}$ lines. Indeed, where investigated, the ratio of activities for propan-2-ol as to ethanol is also greatest for ADH-F enzyme (Lewis and Gibson, 1978; Marson and Birley, unpublished data). In this study the affinity for propan2-ol, of ADH-F enzyme is also lower than that of ADH-S enzyme. Hence differences in the primary structure of ADH-F and ADH-S enzyme are associated with $\mathrm{Km}$ and catalytic efficiency per se. Nonetheless, the difference between $A d h^{F / F}$ and $A d h^{S / S}$ lines in ADH protein in part can be attributed to modifier gene action. For example it may be argued that in vivo, the ADH-F enzyme is less stable, as in vitro it is more thermolabile, than ADH-S enzyme. Therefore, provided that the degree of thermal inactivation of proteins and degree of in vivo protease sensitivity are positively correlated (Lewis and Gibson, 1978), the higher levels of ADH protein, in $A d h^{F / F}$ strains of diverse origin (Day et al., 1974; Lewis and Gibson, 1978), and in our two highly inbred "Texas" $A d h^{F / F}$ lines do not result from increased enzyme level through accumulation of $\mathrm{ADH}$ enzyme in development. Rather the increased level of $\mathrm{ADH}$ protein in these lines is due to modifier loci regulating the rate of enzyme synthesis. If such an associative gametic disequilibrium between modifier loci (us) for high ADH protein level and the $A d h^{F}$ allele is a general feature of ADH polymorphism, it is likely that these two gene-systems function as an effective unit of selection in short-term experiments in the presence of high concentrations of alcoholic substrates and varied temperatures (van Delden et al., 1978).

Genetical variation for ADH activity within $A d h^{s / S}$ lines does not solely reflect variation in the amount of enzyme protein (correlation coefficient, 0.6 q.v. table 4). A study of two $A d h^{s / s}$ lines showed that modification of enzyme activity but not $\mathrm{ADH}$ protein level could be attributed to chromosome III rather than to chromosome II upon which the $A d h$ structural gene is located. Hence there is a strong indication that a posttranslational modification of catalytic efficiency has been effected from chromosome III. Interestingly the substrate affinities of the two $A d h^{s / s}$ lines were very similar.

Criticism of some studies of the genetical control of ADH activity and $\mathrm{ADH}$ protein level has been raised in relation to a 4 -fold environmentally associated variation in ADH protein level (Clarke et al., 1979). These authors obtained a non linear relationship between ADH protein level and body weight and proposed that this invalidated the conventional adjustment of measures of the $\mathrm{ADH}$ phenotype for variation in body size. In this study whilst $\mathrm{ADH}$ activity and $\mathrm{ADH}$ protein level are highly correlated 
the functional origins of gene action are diverse. Some variation in ADH activity and $A D H$ protein may be related to fly size but much of the genetical variation in total protein and body weight is not in common with these characters. Indeed a scaled measure of the ADH phenotype by total protein depends upon the differential expression of total protein in the two sexes. This suggests that scaled measures of the activity phenotype are best avoided since they will tend to increase rather than decrease the contribution of environmental variance.

The genetical control of ADH activity therefore is by alleles which code for $\mathrm{ADH}$ enzymes that differ intrinsically as well as through genetical variation for the control of enzyme quantity and for post-translational modification. Whether the character $\mathrm{ADH}$ activity per se or even the individual components of ADH activity are subject to natural selection in the population "Texas" is open to further question.

Acknowledgements.-We thank Drs D. Richards and D. Stanworth of the Department of Experimental Pathology for assistance with and facilities for preparation of antisera. Dr A. Cornish-Bowden of the Department of Biochemistry is thanked for his advice concerning the determination of Michaelis constants and for a critical reading of the manuscript. Miss P. A. Couch and Mr A. Marson are grateful for S.R.C. Research Studentships. The provision of an LKB Reaction Rate analyser by the Science Research Council was essential to this study. Calculations were carried out on the University of Birmingham's ICL 1906 A Computer.

\section{REFERENCES}

BARNES, B. W., AND BIRLEY, A. J. 1975. Genetical variation for enzyme activity in a population of Drosophila melanogaster. II. Aspects of the inheritance of alcohol dehydrogenase activity in $A d h^{S / S}$ flies. Heredity, 35, 115-119.

BARNES, B. W., AND BIRLEY, A. J. 1978. Genetical variation for enzyme activity in a population of Drosophila melanogaster. IV. Analysis of alcohol dehydrogenase activity in chromosome substitution lines. Heredity, 40, 51-57.

BIRLEY, A. J., AND BARNES, B. W. 1973. Genetical variation for enzyme activity in a population of Drosophila melanogaster. I. Extent of the variation for enzyme activity. Heredity, 31, 413-416.

BIRLEY, A. J., MARSON, A., AND PHILlipS, L. C. 1980. Genetical variation for enzyme activity in a population of Drosophila melanogaster. V. The genetical architecture, as shown by diallel analysis, of alcohol dehydrogenase (ADH) activity. Heredity, 44, 251 268.

CLARKE, B., CAMFIELD, R. G., GALVIN, A. M., AND PITTS, C. R. 1979. Environmental factors affecting the quantity of alcohol dehydrogenase in Drosophila melanogaster. Nature, 280, 517-518.

CORNISH-BOWDEN, A., PORTER, W., AND TRAGER, W. 1978. Evaluation of distribution free confidence limits for enzyme kinetic parameters. J. theor. Biol., 74, 163-175.

DAY, T. H., HILliER, P. C., AND CLARKE, B. 1974. The relative quantities and calalytic activities of enzymes produced by alleles at the alcohol dehydrogenase locus in Drosophila melanogaster. Biochem. Genet., 11, 155-165.

DELDEN, W. VAN., BOEREMA, A. C., AND KAMPING, A. 1978. The alcohol dehydrogenase polymorphism in populations of Drosophila melanogaster. I. Selection in different environments. Genetics, 90,161-191.

EISENTHAL, R., AND CORNISH-BOWDEN, A. 1974. The Direct Linear Plot. A new graphical procedure for estimating enzyme kinetic parameters. Biochem. J., 139, 715-720.

GIBSON, J. B. 1970. Enzyme flexibility in Drosophila melanogaster. Nature, 227, 959-960.

GIBSON, J. B, 1975. Differences in the number of molecules produced by two allelic electrophoretic variants in $D$, melanogaster. Experientia, 28, 975-976.

GIBSON, J. B., AND MIKLOVICH, R. 1971. Modes of variation in alcohol dehydrogenase in Drosophila melanogaster. Experientia 27, 99-100. 
HEWITT, N. E., PIPKIN, S. B., WILliAMS, N., AND CHAKRABARTTY, P. K. 1974. Variation in ADH activity in class I and class II strains of Drosophila. J. Hered., 65, 141-148.

LAURELL, C. B. 1966. Quantitative estimation of proteins by electrophoresis in agarose gel containing antibodies. Anal. Biochem., 15, 45-52.

LEWIS, N., AND GIBSON, J. B. 1978. Variation in amount of enzyme protein in natural populations. Biochem. Genet., 16, 159-170.

MCDONALD, J. F., CHAMBERS, G. K., DAVID, J., AND AYALA, F. J. 1977. Adaptive response due to changes in gene regulation: A study with Drosophila. Proc. Natl. Acad. Sci. U.S.A. $74,4562-4566$.

MARONI, G. 1978. Genetic control of alcohol dehydrogenase levels in Drosophila. Biochem. Genet., 16, 509-523.

MATHER, K., AND JINKS, J. L. 1971. Biometrical Genetics. 2nd Edition. Chapman and Hall Ltd., London.

MEJBAUM-KATZENELLENBOGEN, W., AND DOBRYSZYCKA, W. 1959. New method for quantitative determination of serum proteins by paper electrophoresis. Clinica Chimica Acta., 4, 515-522.

MORGAN, P. 1975. Selection acting directly on an enzyme polymorphism. Heredity, 34, 124-127.

OUCHTERLONY, O. 1967. Immunodiffusion and immunoelectrophoresis. In Weir, D. M. (Editor). Handbook of Experimental Immunology. Blackwell Scientific Publications. Oxford and Edinburgh.

RASMUSON, B., NILSON, L. R., RASMUSON M., AND ZEPPEZAUER, E. 1966. Effects of heterozygosity on alcohol dehydrogenase $(\mathrm{ADH})$ activity in Drosophila melanogaster. Hereditas, 56, 313-316.

SOFER, W. H., AND URSPRUNG, H. 1968. Drosophila alcohol dehydrogenase: purification and partial characterisation. J. Biol. Chem., 243, 3110-3115.

WARD, R. D. 1975. Alcohol dehydrogenase activity in Drosophila melanogaster: a quantitative character. Genet. Res., 26, 81-93. 